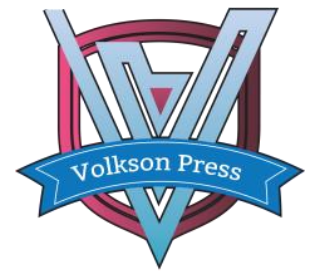

Contents List available at VOLKSON PRESS

Clean Water,Air\&Soil(CleanWAS)

DOI : http://doi.org/10.26480/cleanwas.01.2017.20.23

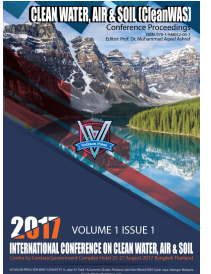

\title{
Study on Green Development of China 's Smart City - Taking Hefei City of Anhui Province as an Example
}

Chen li ${ }^{,}$,Minxiaofei ${ }^{a}$

\author{
${ }^{a}$ School of economics and management of Anhui Jianzhu University, No. 292 Ziyun Road, Hefei, China ${ }^{b}$ School of economics and management of Anhui \\ Jianzhu University, No. 292 Ziyun Road, Hefei, China
}

*Chinalichina@163.com

This is an open access article distributed under the Creative Commons Attribution License, which permits unrestricted use, distribution, and reproduction in any medium, provided the original work is properly cited

\section{ARTICLE DETAILS}

\section{Article History:}

Received 02 october 2017 Accepted 06 october 2017 Available online 11 october 2017

Keywords:

Green development, Smart city, HEFEI, Entropy evaluation

\section{ABSTRACT}

This paper takes the smart city as the research object, introduces the connotation and characteristics of the green development of smart city. The urbanization rate of Hefei is at the forefront of the country. The status of green development of Hefei smart city is studied, including air quality status, water environment quality status, acoustic environmental quality and greening status of Hefei, etc. The paper also established the evaluation index system of the green development of Hefei smart city, and made an empirical evaluation of Hefei smart city by entropy evaluation, the results show that the ecological economy green, resource greening, facility green and environmental green level in the period of 2011 - 2015 have been greatly improved. The statistical yearbook shows that the forest coverage and air quality of Nanjing, the provincial capital of Anhui province, are better than those of Hefei. Although the per capita water resource in Hefei is higher than that in Nanjing, but according to internationally recognized water shortage standards, Hefei is still in the severe water shortage area. Finally, the proposal of green development of Hefei smart city is put forward.

\section{Introduction}

"Smart City" first appeared in an Industrial Technology Association named after the smart city in Las Vegas, USA, in 1984 (Tu ping, 2013).Years later, David.Gibson, George Kozmetsky, Raymond W.Smilor, 1992) published the earliest academic achievements on the study of smart cities. In 2006, Singapore launched a strategically important program," smart nation 2015" (iN2015).In 2007, The European Union put forward a whole set of smart city construction goals and Amsterdam also launched the smart city project in 2008 (ASC, Amsterdam Smart City). At present, there are more than 50 countries and regions have launched a pilot city of wisdom. In February 2009, China began to promote the construction of "smart city ". Smart city is based on the new generation of information technology such as internet of things, cloud computing, wiki, social network, FabLab, LivingLab, comprehensive integration method and other methods to create an ecology conducive to innovation, achieve a comprehensive and thorough perception, broadband ubiquitous interconnection, intelligent convergence applications, and a sustainable innovation characterized by user innovation, open innovation, public innovation and collaborative innovation. When more and more serious urban diseases (such as: population expansion, resource shortage, serious environmental pollution, traffic congestion and increasing public safety hazards, etc.) make the governments and people helpless, the smart city ideas which based on the new generation of information technology bring a new urban life expectation for the governments and people. It is with this expectation of the city sustainable and healthy development that the smart city ideas eventually are accepted by the governments and the people. The emergence of the concept of smart city can supply a better solution to the "urban disease" and achieve the goal of ideal urban sustainable development.

With the acceleration of the Urbanization Process, human activity results in a series of urban environment problems which affects the green development of smart city, such as traffic jam, ecological damage, environmental pollution and lower quality of life. John Knott of Charleston believes that urban green development is " Return to a way of development that combines new technologies and has a good impact on climate, geography and culture "; WK Fong believes that energy consumption and carbon emission reduction are closely related to urban green development; Xiao Hong hold that the green development of cities shift its industrialized development model that only paying attention to the growth of economic benefit, while ignoring the protection of ecological environment, to a model that take into account the development of society, economy, resources and pay attention to the overall benefits of social - economic - natural complex ecological; Zhang Chen holds that the green development of the city should change the development model of one-sided pursuit of economic growth and material expansion; Shi Minjun believes that the gap between domestic urban green development and developed cities is mainly reflected in two aspects: environmental health and low-carbon development.

\section{The connotation and characteristics of smart city green development}

Smart city green development is a new development concept that integrates ecological civilization construction into all aspects of economy, politics, culture and social construction for the first time. The connotation of the smart city green development mainly refers to a model innovation based on traditional development. It is a new type of development model that takes environmental protection as an important pillar for sustainable development, which based on the constraints of ecological environment capacity, resource carrying capacity and regards environmental protection.

Urban green development distinguishes from the traditional economic development. It emphasizes the economic green growth, social harmony, environment-friendly, green ecological cultural construction, green management in the political management aspect and so on. It promotes the urban green transition and ecological civilization construction through the green revolution and the development of economic, social, cultural, environment, politics. The characteristics of smart city green development are efficiency, harmony and continuity. Green development should take the concept of saving priority and efficient use of resources as the starting point, maximize the use of limited resources and improve the efficiency of the development of resources through technological transformation and management innovation, promote harmony between man and nature, people-oriented, realize the reasonable and efficient use of the natural resources, optimize the spatial structure and build the city pattern in a scientific way, so as to promote low-carbon, recycling, sustainable development, and achieve a positive interaction between the social 
economy and the ecological environment.

\section{The present situation of Hefei smart city's green development}

At present, Hefei's urban green coverage rate of $46 \%, 13$ square meters of green space for each inhabitant and the forest coverage rate reached $26.8 \%$.

\subsection{Air quality status}

Hefei City belongs to the national air quality standards for the implementation of the first phase of the city. The average annual concentration of PM10 is 92 micrograms per cubic meter Compared with 2015 , the average annual concentration decreased by $18.7 \%$. The average annual concentration of fine particulate matter (PM2.5) is 66 micrograms per cubic meter, compared with 2015, the average annual concentration decreased by $20.5 \%$, completed the provincial government's annual goal of improving atmospheric environmental quality.

\section{Table 1 Basic data of air quality in Hefei in2015}

\begin{tabular}{|c|c|c|}
\hline Index & $\begin{array}{l}\text { Daily average } \\
\text { concentration } \\
\quad\left(\mathrm{ug} / \mathrm{m}^{3}\right)\end{array}$ & Remarks \\
\hline Sulfur dioxide & 16 & $\begin{array}{l}\text { To meet the national } \\
\text { environmental air quality } \\
\text { level } 1 \text { standard }\end{array}$ \\
\hline Nitrogen dioxide & 33 & To meet the national \\
\hline Carbon monoxide & 1.06 & To meet the national \\
\hline PM10 & 92 & $\begin{array}{l}\text { The annual average of the } \\
\text { air environment quality } \\
\text { year is grade two }\end{array}$ \\
\hline PM2.5 & 66 & $\begin{array}{l}\text { The annual average of the } \\
\text { air environment quality } \\
\text { vear }\end{array}$ \\
\hline \multirow[t]{2}{*}{ Ozone } & $\begin{array}{c}\text { Average daily } \\
\text { average value of } \\
8 \text { hours ( ug / } \\
\mathrm{m}^{3} \text { ) }\end{array}$ & \multirow[t]{2}{*}{$\begin{array}{c}\text { To meet the national } \\
\text { environmental air quality } \\
\text { level } 1 \text { standard }\end{array}$} \\
\hline & 65 & \\
\hline Acid rain & & $\begin{array}{l}\text { Acid rain occurred } 10 \text { times } \\
\text { throughout the year, and } \\
\text { the frequency of acid rain }\end{array}$ \\
\hline
\end{tabular}

Throughout the year, the city's overall environmental quality remained stable and no major environmental incidents occurred.

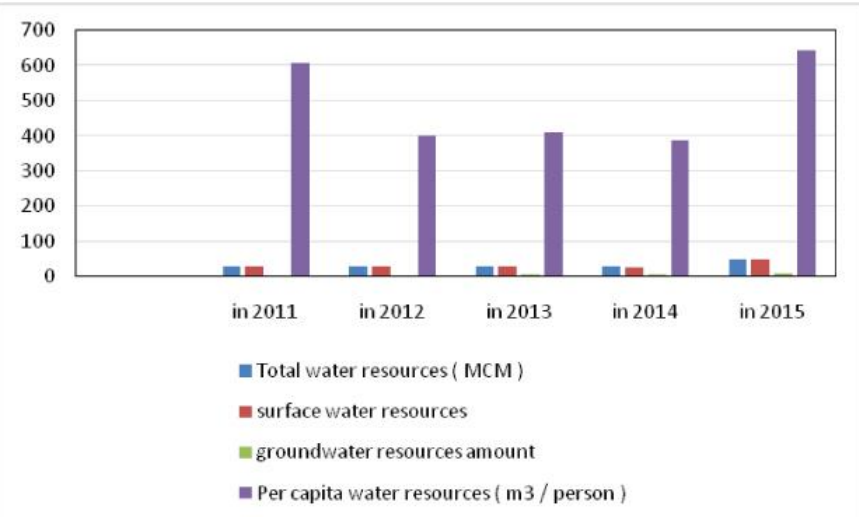

Fig 1. Water resources in Hefei

In recent 10 years, the total amount of water resources in Hefei has been increasing, while the per capita water resources are also increasing. It is indicated that Hefei invested a lot of energy in the protection of water resources, and achieved good results.Dongpu Reservoir and Dafangying Reservoir are the drinking water sources of Hefei. The average value of the indicators monitored in 2016 is in line with GB3838-2002, "Surface Water Environmental Quality Standard" class III water quality standard. Compared with the previous year, the water quality is basically stable. By the end of 2015, 16 projects of the first phase of the Central Chaohu Lake Integrated Management Project were basically completed and the performance evaluation was completed as well. 98 projects of the second phase project were comprehensively advanced; 44 projects of the second phase project are carrying out preliminary design work; There are 13 projects in the fourth phase and $\mathrm{t} 6$ billion 760 million Yuan was invested as a research investment; The five phase of the project takes the Small Watershed Governance as the starting point and implements the comprehensive improvement of the "Shanshui Tianlin Road village". 32 villages and towns sewage treatment plant has been completed and went into operation on the Chaohu Rim.

\subsection{Acoustic environmental quality}

The overall quality of Acoustic Environment of Hefei remains good. The city's regional environmental noise equivalent sound level is $54.4 \mathrm{~dB}(\mathrm{~A})$, the road traffic noise equivalent sound level is $67.7 \mathrm{~dB}(\mathrm{~A})$, these indicators are all in line with the standard value requirements; The noise in the function area meets the requirements of the corresponding functional area standards too.

Table 2 Afforestation status table of each county ( city ) of Hefei ( Hectare) in 2015

\begin{tabular}{l|c|c|c|c|c}
\hline \multirow{2}{*}{ Area } & \multirow{2}{*}{$\begin{array}{c}\text { Total area of a } \\
\text { forestation }\end{array}$} & \multicolumn{4}{|c}{ Classification by use of forest } \\
\cline { 3 - 6 } & & $\begin{array}{c}\text { Artificial a } \\
\text { forestation }\end{array}$ & $\begin{array}{c}\text { Timber } \\
\text { forestry }\end{array}$ & $\begin{array}{c}\text { Economic } \\
\text { forest }\end{array}$ & $\begin{array}{c}\text { Protection } \\
\text { forest }\end{array}$ \\
\hline HEFEI & 15525 & 15498 & 2703 & 4383 & 7748 \\
\hline YAOHAI & 11 & 11 & $\backslash$ & 5 & 6 \\
\hline LUYANG & 212 & 212 & $\backslash$ & $\backslash$ & 212 \\
\hline SHUSHAN & 1686 & 1686 & $\backslash$ & 1686 & $\backslash$ \\
\hline BAOHE & 260 & 260 & $\backslash$ & $\backslash$ & 260 \\
\hline CHANGFE & 2737 & 2737 & 253 & 866 & 1504 \\
\hline FEIDONG & 3448 & 3448 & 435 & 821 & 1792 \\
\hline FEIXI & 2263 & 2263 & 6 & 289 & 1968 \\
\hline LUJIANG & 2544 & 2544 & 112 & 403 & 1852 \\
\hline CHAOHU & 2364 & 2337 & 1897 & 313 & 154 \\
\hline
\end{tabular}

Hefei will launch a new round of returning farmland to forest project. Sloping farmland a slope greater than 25 degrees, terraced fields in important water sources with a slope of 15 to 25 degrees and seriously polluted farmland will be gradually converted with forest. Forestry ecological protection project will be implemented; commercial logging of natural forests will be stopped completely to achieve full coverage of the management and protection areas. Hefei will carry out the public welfare forest cultivation project scientifically, increase the protection of wild animal and plant resources, strictly observe the red line of wetland ecology, and implement wetland protection and restoration project.

In recent years, the scale, standard and effect of forestation in Hefei have been improved. At present, we have over fulfilled the target of "the 12 th Five-Year plan " for forest construction in Hefei.

Table 3 Green space area of Hefei and green coverage area of builtup area in 2015 (Hectare)

\begin{tabular}{l|l|l}
\hline $\begin{array}{l}\text { Area of green } \\
\text { space }\end{array}$ & $\begin{array}{l}\text { The area of park green } \\
\text { space }\end{array}$ & $\begin{array}{l}\text { Green covering area of } \\
\text { built-up area }\end{array}$ \\
\hline 15830 & 4262 & 17807 \\
\hline
\end{tabular}

As of 2015, there have been 25 new parks, 16 upgraded parks, 50 new garden square, 11 upgraded garden square, 25 million square meters of green area built in Hefei. The rate of urban green space, green coverage and park and green land area for each inhabitant were $40.3 \%, 45.2 \%$ and 12.9 square meters. These three criteria were in the forefront of the provincial capital cities in china.

Since entering the "Twelfth Five-Year Plan", Hefei has completed 1 million 350 thousand $\mathrm{mu}$ of a forestation, accounted for $113 \%$ of the province issued tasks, National Forest cities, 3 provincial forest cities, 34 forest towns and 320 forest villages were successfully established. In a 
forestation, Hefei finance department arranged 1 billion 250 million Yuan to grant the municipal key project a forestation. Financial departments at all levels have invested more than 3 billion yuan for the construction of forest growth projects of 10 million mu. At present, the forest area of Hefei has reached 245 million mu, the forest coverage rate has reached $26.8 \%$ and the forest volume is 7 million cubic meters

\section{Entropy weight evaluation}

Reference the urban green development related to the index system and taking into account the availability of data, then design a follow-up related indicators system. The result is shown as the following table.

Table 4Green development evaluation index system of smart city

\begin{tabular}{|c|c|c|}
\hline $\begin{array}{l}\text { Level - I } \\
\text { indicators }\end{array}$ & Secondary indicator & unit \\
\hline \multirow{5}{*}{$\begin{array}{l}\text { Economic } \\
\text { green }\end{array}$} & Per capita GDP & yuan/person \\
\hline & $\begin{array}{l}\text { Energy consumption of ten } \\
\text { thousand yuan GDP }\end{array}$ & $\begin{array}{l}\text { Tons of } \\
\text { standard } \\
\text { coal/wanyuan }\end{array}$ \\
\hline & $\begin{array}{l}\text { Electricity consumption of ten } \\
\text { thousand yuan of GDP }\end{array}$ & $\begin{array}{l}\text { Kilowatt } \\
\text { hours/wanyu } \\
\text { an }\end{array}$ \\
\hline & Land productivity & wanyuan/mu \\
\hline & $\begin{array}{l}\text { The third industry accounts for the } \\
\text { proportion of GDP }\end{array}$ & $\%$ \\
\hline \multirow{4}{*}{$\begin{array}{l}\text { Greening of } \\
\text { resources }\end{array}$} & average per capita water resources & M3/person \\
\hline & $\begin{array}{l}\text { Area of per capita construction } \\
\text { land }\end{array}$ & M2/person \\
\hline & $\begin{array}{l}\text { Science and technology account for } \\
\text { the ratio of fiscal expenditure }\end{array}$ & $\%$ \\
\hline & $\begin{array}{l}\text { Comprehensive utilization ratio of } \\
\text { industrial solid waste }\end{array}$ & $\%$ \\
\hline \multirow[t]{4}{*}{$\begin{array}{l}\text { Greening of } \\
\text { facilities }\end{array}$} & $\begin{array}{l}\text { Every ten thousand people have } \\
\text { the number of buses }\end{array}$ & liang \\
\hline & Gas penetration rate & $\%$ \\
\hline & $\begin{array}{l}\text { Energy saving and environmental } \\
\text { protection expenditure account for } \\
\text { the ratio of fiscal expenditure }\end{array}$ & $\%$ \\
\hline & $\begin{array}{l}\text { Expenditure on transport as a } \\
\text { proportion of fiscal expenditure }\end{array}$ & $\%$ \\
\hline \multirow{5}{*}{$\begin{array}{l}\text { Environme } \\
\text { ntal green }\end{array}$} & forest coverage & $\%$ \\
\hline & $\begin{array}{l}\text { The air quality is up to the } \\
\text { secondary proportion }\end{array}$ & $\%$ \\
\hline & Green coverage of built-up area & $\%$ \\
\hline & Per capita park green space & $\begin{array}{l}\text { Square metre } \\
\text { / person }\end{array}$ \\
\hline & $\begin{array}{l}\text { Rate of harmless treatment of } \\
\text { domestic waste }\end{array}$ & $\%$ \\
\hline
\end{tabular}

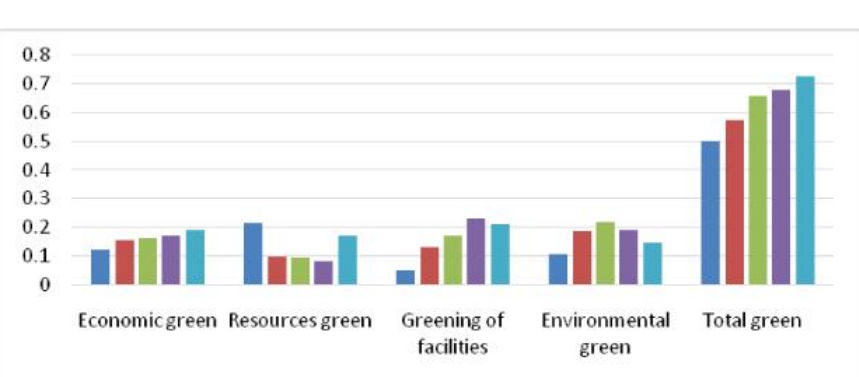

$\|$ in $2011 \|$ in $2012=$ in $2013 \|$ in $2014 \|$ in 2015

Fig 2. Hefei green development level score between2011 to 2015
Based on the weight obtained by entropy method, the dynamic analysis and evaluation of Hefei green development level from 2011 to 2015 were carried out. The ecological economy, green economy, green resources, green facilities and green environment in Hefei have been greatly improved during this period. According to the "statistical yearbook of China", the forest coverage and air quality of Nanjing, the capital of neighboring provinces, are superior to those in Hefei. Although the per capita amount of water resources in Hefei is higher than that in Nanjing, but in accordance with internationally recognized standards of water scarcity, Hefei still belongs to severe water shortage areas.

\section{Conclusion}

Based on the above analysis, the following suggestions can be made for the green development of the smart city in Hefei.

\subsection{Improve the special urban green development plan of Hefei smart city}

Hefei should make further special urban green development planning around the city's green economic development, resource environment protection, government management ability, etc, based on the existing new urbanization development plan of the state.

Roadmap and timetable for urban green development should be designed from various aspects such as the general idea, basic principles, main tasks, development objectives, implementation path, supporting measures and other aspects of the planning, to provide stable and powerful security for city green development.

\subsection{Constructing smart city, meanwhile realizing the greening of economy, resources, facilities and environment}

The construction of smart city should adopt the road of localization and local characteristic development, give full play to the advantages of urban resources, emerge the city region cultural special features, encourage the smart cities to develop in a personalized way. The greening of Hefei smart city's economy should realize a GDP per capita of 85000 Yuan, a GDP energy consumption of 0.38 tons of standard coal / million Yuan and a GDP electricity consumption of $400 \mathrm{kwh} /$ million Yuan. Resources green changes to achieve the goal of land output rate of 80 thousand Yuan / mu, third industry accounted for $55 \%$ of GDP, the per capita amount of 1000 cubic meters of water per person, per capita construction land area of 100 square meters per person, the science and technology expenditure accounted for more than 5\%, 95\% rate of comprehensive utilization of industrial solid waste facilities; The goal of greening facilities: Number of buses per 10000 persons is 24 , gas penetration rate of $100 \%$, energy conservation and environmental protection expenditure accounted for $3.5 \%$, transportation expenditure accounted for $4.5 \%$ of the fiscal expenditure. The goal of green environment is that the forest covers at a level of $28 \%$. More than half the air quality rate as second, urban built-up area green coverage rate areas reached $46 \%$, per capita park green area reaches $15 \%$, garbage harmless treatment rate of $100 \%$ and so on.

\subsection{Improve the policy system of smart city construction environment}

Formulate and implement environmental economic policies to reduce structural pollution. During the "13th five-year plan", Hefei can encourage the role of economic leverage to promote environmental governance, construct a market system for environmental governance and ecological protection by using economic levers, give full play to the role of "invisible hand", promote enterprise environmental cost internalization by economic means, guide and encourage enterprises to change their developmental pattern, improve technology, save resources, reduce pollution. Hefei Environmental Protection Bureau may establish the environmental economic policy framework and roadmap; union bank, finance department and other units can launch a series of economic policies, such as price, taxation, finance, credit, fees and insurance to promote the development of green city.

\subsection{The wisdom of urban construction, the full implementation of green cleaner production}

Hefei city should promptly formulate "opinions on promoting green cleaner production in an all-round way" and make over all planning to promote cleaner production in Hefei. Focus on the establishment of a uniform harmony mechanism for cleaner production, innovation of audit acceptance methods, establish differentiated incentive mechanisms and improve job security mechanism and other aspects of breakthrough. Hefei should carry out the unified management of voluntary and compulsory cleaner production audit, promote clean production mode, simplifying the 
process cleaner production audit, and form a green cleaner production implementation model of "the Government takes the lead, multispectral collaboration".

Hefei should improve the cleaner production by organic combination of the development of circular economy and the elimination of structural pollution. Strengthen the promotion and use of clean production technology and scientific research; make it act on pollution abatement in time. Encourage enterprises to carry out cleaner production audit, implement ISO14000 environmental management system standards certification and incorporate cleaner production concepts into their routines. Speed up the formation of the cleaner production in Construction , the full implementation of green construction, implementation of site recycling of engineering waste, exploration of the establishment of green building construction responsibility system and supervision mechanism to treat site pollution with minimization and harmless.

\subsection{Create a livable ecological environment of wisdom}

First of all, we should improve the water environment on continuous improvement and focus on strengthening the safety protection of drinking water sources. We must carry out special measures for centralized drinking water sources, strengthen the risk prevention of poisonous chemicals transport ships to ensure the stable rate of centralized drinking water sources in the city to maintain $100 \%$.To ensure the safety of drinking water for residents It is important to improve the water quality of waterworks, complete the advanced treatment of water quality in urban waterworks and complete the transformation of social water supply in enterprise owned waterworks, so as to guarantee the safety of drinking water for residents. Secondly, to e ensure the stability of air quality and continuous improvement, the government should strengthen the prevention and control of industrial pollution emissions, improve air quality, focus on remediation of vehicle exhaust pollution and straw burning pollution control, carry out regional joint prevention and control and reduce the pollution load, so that the general public may have a place to enjoy some fresh air. Overall, strengthen the management of garbage; reduce the solid waste with harmless method. Strengthen the classification and recovery of municipal solid waste, improve the collection and treatment facilities construction; strengthen the comprehensive utilization and management of industrial solid waste and construction waste; take the strictest management and proper pollution control of hazardous waste.

\section{Acknowledgments}

Foundation item: The project was financially supported by 2017, Anhui University Humanities and social science research key project: Anhui Construction University - Anhui construction economy and real estate management research center, "big data background of smart city green development research"(number: SK2017A0548)

\section{References}

[1] Mahizhnan(1999, J anuary).A.Smart cities: the Singapore cas.Cities,16(1),13-18

[2] Jianghuilian,Wanglida,Zhangshaotong(2013, April). International practice and Enlightenment of smart city construction and evaluation . $E$ government, 4, 10-17

[3] zhangzhengang,Zhangxiaojuan (2013, June).Review and Prospect of smart city research . management modeation, 6,126-128

[4] Lichongzhao,Liushuhua (2011, June).Smart city: a new trend of urban governance in China. E-government, 6,13-18

[5] Wangning, Wangyeqiang (2015, April).A review of smart city studies and implications for new urbanization. City Watch, 4,151 -159

[6] Tuping, Chenli. (2013, Auguest). Inspiration of foreign smart city construction. technology think tank, 8, 64 - 69

[7] Lihaijun (2012, June). The concept of smart city. intelligent architecture and urban information , 6, 11-16

\section{Appendixes}

Author introduction:

Li Chen (1966-), female, the vice president of college of management, Anhui Jianzhu University, professor, master tutor, Ph.D., mainly engaged in theory and evaluation of technical and economic,tel:13339296584,address:Southern District of Anhui Jianzhu University, 292 Ziyun Street, Economic Development Zone, Hefei, Anhui, China.

Minxiaofei(1992-), male, Urban Construction College of AHJZU, Hefei, Anhui, China, engaged in theory and evaluation of technical and economic 